\title{
MENINGKATKAN KUALITAS PERMBELAJARAN MELALUI ACTION RESEARCH
}

\author{
Iin Wariin B. \\ Fakultas Keguruan dan Ilmu Pendidikan, Universitas Swadaya Gunung Jati \\ iinwariinbasyari@gmail.com
}

\begin{abstract}
Abstrak
Tujuan penulisan makalah ini adalah untuk mengembangkan wawasan teoritis tentang Class Action Research. Secara teoritis Class Action Research dapat berkontribusi terhadap upaya meningkatkan kualitas pembelajaran. Sebab produk penelitian ini memberikan informasi praktis untuk mengatasi berbagai masalah hambatan belajar dan pembelajaran di kelas. Makalah disusun melalui studi literature serta pengalaman penulis sebagai peneliti. Ada tiga hal penting yang dipaparkan dalam makalah ini. Pertama, konsep dan teori tentang Class Action Research. Kedua, menjawab pertanyaan bagaimana prosedur menyelenggarakan Class Action Research. Ketiga, mengeksplorasi keunggulan dari Class Action Research. Karena sifat dan karakteristiknya maka Class Action Research dapat dikategorikan ke dalam jenis penelitian kualitatif, yang bersifat naturalistic, reflektif, kolaboratif dan cyclical. Keunggulan pendekatan jenis penelitian ini adalah memiliki meaningful yang langsung dapat dirasakan dan dipraktikkan dalam penyelenggaraan pembelajaran sehari-hari bagi seorang guru maupun dosen. Semakin sering guru atau dosen melakukan penelitian melalui pendekatan ini, akan semakin cepat guru atau dosen dalam memperkaya kompetensi pedagogisnya.
\end{abstract}

Kata Kunci: Class Action Research; meaningful; penelitian kualitatif; naturalistic; reflektif; cyclical.

\section{PENDAHULUAN}

Seiring dengan perkembangan ilmu pengetahuan dan teknologi pendidikan, hal itu berimplikasi terhadap berkembangnya berbagai model, pendekatan, metode dan strategi pembelajaran. Joyce dan Weil (2010) membagi model pembelajaran kedalam empat kelompok. Pertama, kelompok pengajaran model-model pengelohan informasi dengan penekanan pengembangan kognisi dan berpikir induktif. Kedua, kelompok pengajaran model-model personal yang bersifat kemandiran siswa dalam belajar. Ketiga, kelompok model-model pengajaran sosial yang lebih menekankan pengembangan kecerdasan dan ketrampilan social social siswa. Keempat, kelompok pengajaran model-model perilaku yang menekankan pada proses pembelajaran yang mandiri, kontekstual dan beroikir sederhana pada yang lebih kompleks. Model-model tersebut merupakan teknologi pembelajaran yang inovatif untuk mengakomodasi kompleksnya tujuan dan materi pembelajaran yang berkembang dewasa ini. Sehingga dosen dituntut untuk mengembangkan dan mengimplementasikan-nya dalam pembelajaran di kampus.

Banyaknya model pengajaran hasil penelitian pakar pendidikan sudah seharusnya dosen untuk mengimlementasikan dalam melaksanakan pendidikan dan pengajaran di perguruan tinggi masing-masing. Pembelajaran yang dilaksanakan dosen harus efektif sebagaimana amanat Negara melalui Permenristekdikti Nomor 44 Tahun 2015 Bagian Keempat Pasal 14 (2) bahwa "Proses pembelajaran melalui kegiatan kurikuler wajib menggunakan metode pembelajaran yang efektif sesuai dengan karakteristik mata kuliah untuk mencapai kemampuan tertentu yang ditetapkan dalam matakuliah dalam rangkaian pemenuhan capaian pembelajaran lulusan". Efektifitas tidaknya pembelajaran sangat ditentukan oleh tingkat kompetensi dosen 
dalam menggunakan model, pendekatan, metode, strategi dalam pembelajaran.

Mengembangkan kompetensi pembelajaran dosen melalui program Pekerti atau Applaid Approach (AA) atau sejenisnya seperti diklat atau kursus sudah barangtentu tidak akan efektif mengingat waktu penyelenggaraan dan materinya yang sangat terbatas. Salah satu alternatifnya adalah melalui Action Researh. Dimana dosen melalui proses refleksi menemukan permasalahan pembelajaran lalu memecahkannya melalui pendekatan empiric yang sistematik dan metodik melalui tindakan dikelas dengan melibatkan mahasiswa sebagai subejek penelitian dan berkolaborasi dengan kolega untuk menghasilkan data yang seobjektif mungkin.

Dalam dunia pendidikan Action Risearch tergolong relative masih baru. Diawali oleh Kurt Lewin pada tahun 1940 an, yang menyimpulkan bahwa penelitian tindakan merupakan suatu proses yang memberikan kepercayaan pada pengembangan kekuatan berpikir reflektif, diskusi, penentuan keputusan

\section{PEMBAHASAN}

1. Pengertian Action Research Menurut Sukmadinata (2012) Ada dua teori yang melandasi peneltian tindakan. Pertama penelitian tindakan yang merujuk pada teori kritis yang bersumber pada aliran postmodernism. Dari teori tersebut melahirkan penelitian tindakan kritis (critical action research). Kedua penelitian yang kedua menekankan proses tindakan. Lebih bersifat praktis dan aplikatif yang kemudian melahirkan penelitian tindakan praktis (practical action research).

Perbedaan pada kedua landasan teori tersebut terletak pada focus dan tujuannya. Fokus dan tujuan pada jenis pertama lebih mengedepankan pada upaya menemukan dan tindakan oleh orang-orang biasa, berpartisipasi dalam penelitian kolektif dalam mengatasi kesulitan-kesulitan yang mereka hadapi dalam kegiatannya, Sukmadinata (2012).

Lalu muncul jenis penelitian yang sama yang dilakukan oleh Stephen Corey pada taun 1952-1953. Lalu Council's Humanities Curriculum Project (HCP) pada tahun 19671972 di Inggris, Ford Teaching Project (tahun 1972-1975) dipimpin oleh John Elliot dan Clem Adelman dan Classroom Action Research (tahun 1976) berpusat di Institut Cambridge (Sagala,2013).

Tulisan ini merupakan kajian literature yang tujuannyanya adalah untuk memberikan pengetahuan dan wawasan tentang konsep Action Research serta menumbuhkan kesadaran sikap tentang pentingkanya peningkatan kualitas pembelajaran dalam melaksanakan Tridharma Perguruan Tinggi khususnya pada ranah Pendidikan dan Pengajaran sekaligus memenuhi tuntutan Penelitian dan Pengabdian Kepada Masyarakat.

kebenaran-kebenaran empiric pada tataran yang terbatas, situasional dan kondisional. Sedangkan pada jenis yang kedua focus dan penelitian lebih bersifat terapan atau aplikatif yang harus meaningfull untuk perbaikan-perbaikan dalam praktik pelayanan sosial dalam hal ini pembelajaran.

Di kalangan sekolah penelitian ini dikenal dengan istilah Penelitian Tindakan Kelas (PTK) merupakan terjemahan dari bahasa Inggris yaitu Class Action Research. PTK Sebenarnya merupakan aplikasi atau implementasi dari penelitian sosial yang tergolong pada jenis Penelitian Tindakan (Action Research). Yang "aplikasi dan pemanfaatan pada umumnya 
adalah dalam bidang sosial, terutama dalam rangka melakukan perubahan atau perbaikan sosial".2). Sebagaimana umumnya, penelitian ini bisa dilakukan oleh perorangan atau kelompok. Hanya sifatnya untuk memecahkan persoalanpersoalan sosial pada ruang lingkup yang relative terbatas. Sebagaimana dikemukakan oleh Fraenkel dan Wallen (1990) bahwa: " Action Research is research conducted by one or individual or group for the purpose of solving a problem or obtaining information in order to inform local practice. Karena ruang lingkup penelitian ini relative terbatas, maka penelitian jenis ini dapat dilakukan oleh para dosen atau guru pada subjek yang dangat terbatas yaitu kelas. Namun demikian tidak mengurangi nilai kebermanfaatan (benefit) dari penelitian itu sendiri.

Dalam dunia pendidikan dan pengajaran jenis penelitian ini biasanya dilakukan di kelas (dalam arti kelompok belajar) dan bertujuan untuk memecahkan masalahmasalah pembelajaran, sehingga dikenal dengan istilah Penelitian Tindakan Kelas (Class Action Research) untuk selanjutnya digunakan istilah Action Research. Action Research sudah barang tentu subjek penelitiannya adalah mahasiswa dengan perlakuan tertentu. Kepentingannya bukan semata-mata untuk melihat produk suatu perlakuan, tetapi lebih menekankan pada suatu proses tindakan pembelajaran sebagaimana dikemukan oleh Biggs, 2003 bahwa "...action research is being systematic about changing your teaching and making sure the change are in the right direction; that your student are now learning better than they use to. The target of action learning is the teaching of the individual teacher herself or himself" Alwasilah (2011).
Produk pembelajaran sendiri hanya sebatas sebagai media untuk meyakini akan perbaikan suatu tindakan, dengan asumsi dasar makin baik perlakuan makin baik pula hasil belajarnya. Jadi focus dari penelitian tindakan adalah bagaimana guru memperbaiki kenerja pada persoalan tertentu, dan ini bermanfaat bagi guru yang bersangkutan.

Di kalangan para dosen pemula yang berlatar sarjana MIPA non pendidikan baik dari kelompok pure sciences maupun applied sciences mungkin belum familier dengan baik teori maupun praktik Action Research. Untuk sedikit memahami apa hakekat dari penelitian tindakan, di bawah ini digambarkan dengan singkat beberapa hal yang membedakan antara penelitian tindakan dengan penelitian lain yang sudah dikenal dikalangan para sarjana pada umumnya. Perbedaan tersebut meliputi landasan filosofis, tujuan, sumber masalah, subjek penelitian, proses penelitian dan lain-lain.

Pada Matrik 1 terdapat perbedaan yang mendasar antara Action Researh dengan penelitian dengan penelitian jenis-jenis lainnya. Pertama, menurut Meleong (2017) dari aspek filosofis Action Research berbasis pada paradigma fenomenologis, sebagai suatu paradigma yang 'berusaha memahami perilaku manusia dari segi kerangka berpikir maupun bertindak orangorang itu yang dibayangkan atau dipikirkan oleh orang-orang itu sendiri'. Kedua, Darmadi (2015) sumber masalah Action Research adalah dari catatan dan hasil refleksi yaitu sebagai "suatu upaya evaluasi dan penilaian, dan refleksi ini perlu adanya upaya kritik sehingga dimungkinkan pada tarap evaluasi terhadap perubahanperubahan.

Ketiga, tujuan Action Research dalah semata-mata lebih menekankan pada 
perbaikan kualitas proses. Dalam hal ini proses pembelajaran, mulai dai perencanaan, pelaksanaan pembelajaran dari tahap membuka pembelajaran, kegiatan inti sampai pada menutup pembelajaran. Perbaikan pada proses juga termasuk perbaikan hardware pembelajaran, seperti fasilitas pembelajaran seperti media pembelajaran, buku, atau properti pembelajaran yang diperlukan apabila dalam pembelajaran tersebut dilakukan melalui pendekatan praktikan dan workshop.

Keempat, status pelaku riset pada Action Research memposisikan dirinya sebagai human instrument yang mampu melakukan partisipasi langsung dengan subjek penelitian dan menggali informasi dari informant. Dengan demikian pelaku riset dalam proses penelitian harus melibatkan kolega sebagai observer untuk memperkaya baik yang diperlukan untuk refleksi dan analisis. Itulah sebabnya penelitian ini dikenal dengan istilah penelitian reflektif dan kolaboratif.

Kelima, desain proses penelitian pada Action Research adalah cyclical. Artinya proses tindakan dilakukan berulang sampai pada tingkat kepuasaan ekspetasi peneliti. Keenam, sampel dalam Action Research tidak menekankan keterwakilan sampel terhadap populasi mengandung makna bahwa subjek penelitian itu bersifat purposive sample. Ketujuh, metode penelitian lebih fleksibel artinya bahwa pada Action Research bias terjadi antara siklus satu ke siklus selanjutnya metode pengumpulan data, i9nstrumen dan teknik analsisnya berubah-rubah. Bukan tidak mungkin pengumpulan data kuantitatif diperlukan sepertu untuk mengukur tingkat kognisi subjek penelitian umpamnya. 
Tabel 1. Matrik 1 Perbedaan Research Action dengan Jenis Penelitian Lain

\begin{tabular}{|c|c|c|}
\hline Dimensi & Penelitian Tindakan & Penelitian Lain \\
\hline Filosofis & - Memperbaiki realita & 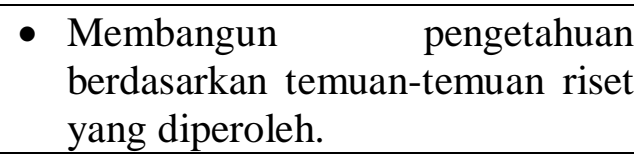 \\
\hline $\begin{array}{l}\text { Sumber } \\
\text { masalah }\end{array}$ & $\begin{array}{l}\text { - Hasil diagnosis kegiatan yang } \\
\text { dilakukan secara rutin. }\end{array}$ & $\begin{array}{l}\text { - Hasil proses deduksi induksi atau } \\
\text { induksi-deduksi. }\end{array}$ \\
\hline Tujuan & $\begin{array}{l}\text { - Memperbaiki dan meningkatkan } \\
\text { kualitas pelayanan, yang selama } \\
\text { ini dilaksanakan. } \\
\text { - Mengetahui apa yang sedang } \\
\text { terjadi dalam kegiatan pelayanan } \\
\text { sosial/organisasi dan lain-lain. } \\
\text { - Perubahan ke arah perbaikan. } \\
\end{array}$ & $\begin{array}{l}\text { - Verifikasi dan generalisasi. } \\
\text { - Mengetahui apa yang sudah } \\
\text { terjadi. } \\
\text { - Memberikan saran }\end{array}$ \\
\hline $\begin{array}{l}\text { Status pelaku } \\
\text { riset }\end{array}$ & $\begin{array}{l}\text { - Peneliti sebagai partisipan yang } \\
\text { berkolaborasi dengan sejawat } \\
\text { atau fasilitator. }\end{array}$ & $\begin{array}{l}\text { - Sebagai orang luar yang berusaha } \\
\text { memahami dan mencari jawaban } \\
\text { terhadap masalah riset. }\end{array}$ \\
\hline Desain Proses & - Siklus tindakan & - Linier tidak bersiklus \\
\hline Sampel Riset & $\begin{array}{l}\text { - Tidak menekankan keterwakilan } \\
\text { sampel terhadap populasi. }\end{array}$ & $\begin{array}{llr}\text { - Sangat penekankan pada } & \text { pant } \\
\text { keterwakilan sampel } & \text { untuk } \\
\text { menghasilkan generalisasi. } & \\
\end{array}$ \\
\hline Metode & $\begin{array}{l}\text { - Menggunakan metode yang lebih } \\
\text { fleksibel dalam beberapa siklus. }\end{array}$ & $\begin{array}{l}\text { - Menggunakan metode yang lebih } \\
\text { tetap dalam proses riset yang } \\
\text { bersifat linier. }\end{array}$ \\
\hline
\end{tabular}

Sumber : Ali (2011) 
Dari penjelasan tersebut di atas maka produk Action Research setidak-tidaknya akan menghasilkan teori pada tataran locally, dan temuan teori tersebut tidak bersifat genaralise. Namun kebermaknaanya dapat dirasakan oleh peneliti itu sendiri. Namun bukan berarti kebermaknaan produk penelitian terbatas pada hasil subjek penelitian semata. Sebab teori-teori itu dapat pula dijadikan rujukan untuk menerapkannya pada kelas lain yang karakteristik yang identik dengan subjek penelitian yang telah dilakukan peneliti.

Keunggulan Action Research terletak pada karakteristik dari penelitian ini. McNiff \& Whitehead, 2003 (Madya, 2006) mengidentifikasi delapan karakter yaitu: (1) penelitian tindakan berbasis praktisi, yang manfaatnya langsung dapat dirasakan bagi dosen dan mahasiswa. (2) penelitian ini difokuskan pada tindakan (learning). (3) merupakan praktik profesional yang baik bagi dosen karena dalam penelitian ini melibatkan pada pengembangan pengetahuan, ketrampilan dan moralitas yaitu tanggung jawab. (4) Penelitian tindakan dapat mengarah pada pribadi dan tindakan sosial. (5) Penelitian tindakan responsif pada situasi sosial. (6) Penelitian tindakan kelas menuntut pertanyaan tingkata tinggi. Artinya tidak hanya sekedar "Apa" atau "Apakah?" Tetapi bisa berupa pertanyaan "Bagaimana?". (7) Praktisi bertanggung jawab atas tindakannya sendiri, (8) penelitian tindakan menekankan nilai-nilai sebagai dasar praktik.

2. Langkah-Langkah Penelitian Tindakan

Penelitian tindakan berangkat dari kesadaran seorang dosen terhadap adanya suatu persoalan yang krusial dalam penyelenggaraan pembelajaran yang dilakukannya. Atas dasar kesadaran tersebut maka merasa perlu adanya perbaikanperbaikan yang bersifst empiric dan sistematik dengan merujuk pada teori-teori yang ada sebelumnya. Dengan demikian sumber masalah penelitian pada penelitian tindakan berawal dari temuan-temuan atau pengamatan dosen selama melakukan pembelajaran pada tema dan pendeaktan tertentu.

Temuan permasalahan pembelajaran dapat diperoleh melalui refeleksi, yang sumbernya diperoleh dari dokumen hasil pembelajaran, reaksi-reaksi sosial mahasiswa selama dalam proses pembelajaran, atau keluhan mahasiswa pada waktu mengikuti pembelajaran. Selanjutnya persoalanpersoalan tersebut diidentifikasi dan ditindak lanjuti dengan langkah-langkah untuk memperbaikinya.

Dari berbagai sumber Madya (2006, hlm. 102 ) merumuskan langkah-langkah $\mathrm{AR}$ meliputi (1) mengidentifikasi dan merumuskan masalah, (2) menganalisis masalah, (3) merumuskan hipotesis tindakan, (4) membuat rencana tindakan dan pemantauannya, (5) melaksanakan tindakan dan mengamatinya, (5) mengolah dan menapsirkan data, (6) kesimpulan.

a. Mengidentifikasi dan merumuskan masalah

Secara sederhana masalah dapat dimaknai sebagai suatu kesenjangan antara harapan dan kenyataan. Besar kecilnya masalah tergantung dari seberapa besar kesenjangan atara keduanya. Harapan biasanya merujuk pada teori atau standarstandar yang bersifat normative. Sedangkan kenyataan lebih bersifat kepada hal-hal yang bersifat empiric dan factual. Sebagaimana diuraikan di atas, bahwa latar belakang permasalahan dalam Action Researh berangkat dari kesadaran dosen tentang adanya persoalan yang krusial dalam penyelenggaraan pembelajarannya. Sumber informasi tersebut dapat diperoleh melalui refleksi, pengamatan, catatan harian, sumber dokumen serta sumber lainnya yang sahih. Dosen menyadari bahwa apabila permasalahan tersebut tidak diselesaikan maka akan berdampak pada buruk pada capaian pembelajaran. Dari temuan-temuan empiric tersebut, selanjutnyanya dosen melakukan identifikasi masalah. Contoh identifikasi masalah (1) rendahnya ketrampilan berpikir analisis pada mahasiswa, 
(2) rendahnya partisipasi aktif mahasiswa dalam pembelajaran bahasa Inggris. (3) rendahnya kualitas pembelajaran pada Mapel Kalkulus. Identifikasi juga dapat menggunakan pendekatan tematik.

Setelah melakukan identifikasi maka dipilih masalah yang sekiranya "paling besar sumbangannya terhadap mutu hasil pendidikan hususnya mutu kemampuan dan pribadi siswa dan mahasiswa, umpamanya implementasi kurikulum" (Sukmadinata, 2012, 147). Oleh karena itu sebelum merumuskan suatu masalah hendaknya dosen melakukan analisis masalah terlebih dahulu. Media yang digunakan untuk menganalisis masalah bisa diskusi, kajian pustaka dan lainlain. Contoh masalah dan rumusannya dikutip dari Mulya (2012, hlm. 110) sebagai berikut. Masalahnya adalah Rendahnya kemampuan mengajukan pertanyaan kritis di kalangan mahasiswa. Adapun rumusannya adalah Mahasiswa semester 5 mestinya telah mampu mengajukan pertanyaan yang kritis, tetapi dalam kenyataannya pertanyaan mereka lebih bersifat klarifikatif.

b. Merumuskan Hipotesis Tindakan

Hopotesis pada penelitian tindakan sangat berbeda dengan hipotesis pada penelitian lainnya terutama pada metode kuantitatif. Sehingga ada istilah Ha dan Ho. Rumusan hipotesis pada Action Research mesti menggambarkan tindakan atau perlakukan untuk meningkatkan atau memperbaiki proses. Sehingga bias saja setiap siklus tindakan ada rumusan hipotesis.

c. Membuat Rencana Tindakan

Menurut McNiff et.al, 2003, (Madya, 2012, 120), dalam membuat perencanaan harus berangkat dari pertanyaan sebagai berikut (1) apa persoalan yang diangkat?, (2) mengapa persoalan itu telah dipilih?, (3) jenis bukti apa yang dapat diproduksi untuk menunjukkan perubahan telah terjadi?, (4) apa yang akan dilakukan dengan temuan ? (5) Bukti apa yang dapat diproduksi untuk menunjukkan bahwa tindakan terkait memiliki dampak? (6) Bagaimana dampak akan dievaluasi ? (6) Bagaimana penelitian menjamin bahwa penilaian yang akan dibuatnya bersifat adil dan akurat? (7) Bagaimana praktik akan dimodifikasi berdasarkan hasil evaluasi. Dari uraian ini dapat disimpulkan bahwa di dalam perencanaan penelitian setidak-tidaknya (1) menentukan subjek penelitian, (2) menyusn desain penelitian, (3) menyusun tehnik pengumpulan data, (4) menyusun tehnik analisis dan validasi data.

d. Pelaksanaan Penelitian

Sebagaimana diuraikan di atas, bahwa penelitian ini bertujuan untuk melakukan perubahan terhadap capaian pembelajaran yang sesuai dengan harapan baik bersifat instructional effects maupun nurturant effects. Sehingga proses penelitian yang dilakukan berorientasi pada kualitas perlakuan yang divalidasi dengan mengukur hasil atau capaian pembelajaran yang diinginkan.

Dalam proses tindakan peneliti memulainya dengan menyusun perencanaan pembelajaran. Selanjutnya dilakukan penelitian tindakan melalui proses pembelajaran. Pada saat proses tindakan ini observer dengan menggunakan instrument observasi yang telah disiapkan melakukan observasi dari awal sampai ahir pembelajaran. Observasi itu sendiri bisa dalam bentuk pengamatan dan pengukuran proses. Komponen yang diobservasi bisa berupa aktivitas/kinerja dosen, aktivitas mahasiswa, sistem sosial dalam kelas, prinsip reaksi mahasiswa terhadap proses pembelajaran, simtem pendukung pembelajaran dan lain-lain (alat bantu observasi bisa saja dengan menggunakan kamera dan alat perekam suara). Apabila penelitian tindakan tersebut menuntut adanya posttest maka pada ahir pembelajaran dilakukan pengukuran tingkat capaian pembelajaran baik pada ranah kognitif atau ketrampilan. Menurut Ali (2012, hlm. 344) rangkaian siklus itu meliputi tahapan refleksi, perencanaan, tindakan dan observasi. 
Hasil observasi dan pengukuran merupakan bahan dan aspek yang dipertimbangkan pada saat peneliti atau dosen melakukan refleksi. Dari refleksi ini sudah barang tentu peneliti mendapat temuantemuan. Selanjutnya temuan-temuan tersebut diidentifikasi dan dijadikan pertimbangan dalam memperbaiki atau merevisi perencanaan pembelajaran pada siklus kedua.

Proses ini terus berulang sampai pada pada titik jenuh, tapi variable-variabel yang dilalui dari setiap siklus relative sama. Lebih lanjut Alwasilah (2011, 154) memaparkan bahwa Action Research diawali dengan fase diagnosis untuk mengetahui persoalan (penyakit) dalam pembelajaran (bisa mahasiswa sebagai peserta atau guru sebagai penyelenggara pembelajaran). Dalam istilah Action Research disebut fase 1.

Fase kedua, adalah fase dimana dilakukan tindakan ke 2 atau siklus kedua. Belajar dari persoalan atau penyakit pada fase diagnosis tadi, maka peneliti melakukan reflektif untuk melakukan perbaikanperbaikan baik pada perencanaan, maupun perlakuan. Pada fase ini semestinya akan mulai terlihat adanya perubahan ke arah yang lebih baik.

Fase ketig, fase ini disebut dengan istilah siklus 3, fase dimana kualitas pembelajaran sudah mencapai dengan apa yang diharapkan oleh peneliti. Karena pada fase ini segala persoalan yang didiagnisis mulai pada satu sampai fase dua menjadi lebih gamblang dan jelas, sehingga persoalan yang dihadapi semakin focus. Pada ahirnya Action Research akan menghasilkan simpulan baik secara teoritik maupun praktik. Teoritik akan mengembangkan epistemology pembelajaran di kelas pada lingkup yang bersifat spesipik. Sedangkan praktik akan menghasilkan kinerja pembelajaran yang dilandasi dengan prosedur dan tindakan edukatif dan didaktik yang ideal pada tataran tema pembelajaran, metode, atau lingkup kelas tertentu. e.

eknis Analisis

Secara procedural, proses analisis data pada Action Research sudah harus dilakukan semenjak proses penelitian di lakukan. Karena hasil analisis siklus pertama akan berimplikasi pada perbaikan tindakan pada siklus selanjutnya. Apabila peneliti dirasa perlu memperkaya hasanah pengetahuan dan data agar action research siklus selanjutnya lebih baik, bisa saja untuk jangka waktu tertentu penelitian dihentikan sementara.

Mills 2000 (Sukmadinata, 2012, 156), ada delapan tehnik analisis dalam Action Research yaitu: (1) mengidentifikasi tematema, (2) membuat kode pada hasil survey, interview dan angket, (3) mengajukan pertanyaan-pertanyaan kunci, (4) membuat review keorganisasian dari unit-unit yang diteleti, (5) membuat peta konsep, (6) analisi factor, (7) buat bentuk-bentuk penyajian dari temuan, (8) kemukakan apa yang belum/tidak ditemukan.

Pertama, tema dapat diidentifikasi dari data yang bersifat induktif kedalam tematema tertentu. Mulai dari tema membuka pembelajaran, kegiatan inti sampai penutup, bisa pula tema dalam hal sistem sosial, sistem pendukung, sintak dan lain-lian. Kedua, membuat kode-kode untuk setiap tema atau kelompok. Ini penting karena penelitian yang bersifat kualitatif cenderung data induktif itu diperoleh dengan tak beraturan muncul dari situasi yang bisa berbeda-beda. Ketiga mengajukan pertanyaan bisa dalam bentuk 'siapa, apa, kapan, mengapa, bagaimana? Kesemua pertanyaan tersebut menggiring kita untuk memperoleh dan sekaligus mengidentifikasi masalahmasalah yang muncul sesuai dengan tema dan kelompoknya. Keempat, melakukan review keorganisasian, seperti review terhadap visi dan misi penelitian, masalah penelitian, struktur organisasi pelaksanaan dan lain-lain. Keenam, menganalisasi factor-faktor yang mendahului, analisis factor ini penting dilakukan mengingat proses penelitian yang dilakukan bersifat siklus dan 
berkesinambungan antara siklus yang satu dengan sikus yang lainnya. Karena kalau tidak dilakukan analisis awal maka dihawatirkan akan terjadinya missinglink antar siklus. Dari analiais ini ketujuh menyajikan bentuk-bentuk temuan tersebut bisa dalam bentuk tabel, peta konsep, bagan atau gambar. Terahkir kedelapan mengidentifikasi apa yang belum ditemukan atau belum diharapkan oleh peneliti sesuai dengan tujuan awal.

\section{Usulan Action Research}

Merujuk pada Panitia Rayon Pendidikan dan Latihan Profesi Guru (PLPG), kerangka usulan Action Research sebagaimana pada umumnya usulan-usulan dalam bentuk proposal penelitian. artinya banyak formatformat yang secara struktur keorganisasian mungkin berbeda, namun pada umumnya secara subtansi sama.

Pada format PLPG ada tiga bagian yang harus diinformasikan kepada pihak yang memiliki otoritas apakah ususlan itu diterima atau ditolak. Pertama bagian Pendahuluan, diawali dengan judul penelitian, (1) Latar Belakang Masalah , (2) Rumusan Masalah , (3) Tujuan Penelitian dan (4) Manfaat Penelitian. Kedua Landasan Teoritis , yang meliputi (1) Landasan Teori, (2) Penelitian yang Relevan (jika ada), (3) Kerangka Berpikir dan (4) Hipotesis Tindakan. Ketiga Metodologi Penelitian yang meliputi (1) Setting Penelitian, (2) Subjek Penelitian, (3) Sumber Data, (4) Teknik dan Alat Pengumpulan Data, (5) Validasi Data, (6) Analisis Data, (7) Indikator Kinerja, (8) Prosedur Penelitian.

\section{SIMPULAN}

Action Researh merupakan salah satu sarana dosen untuk meningkatkan kualitas dan perbaikan pembelajaran yang dilakukan secara terencana, sistematik, teoritik dan empiric. Sebagai dosen yang professional, sudah barang tentu manfaatnya dapat dirasakan langsung baik oleh dosen sendiri maupun kepada mahaiswa, yang pada gilirannya akan berdampak pada meningkatnya kontribusi institusi terhadap pembangunan sumber daya manusia Indonesia.

\section{DAFTAR PUSTAKA}

Ali, M. (2012). Memahami Riset Prilaku Dan Sosial. Bandung: Pustaka Cendikia Utama.

Alwasilah, A.,Ch. (2011). Pokoknya Action Research. Bandung: PT Kiblat Buku Utama.

Darmadi, H. (2015). Desain dan Implementasi Penelitian Tindakan Kelas (PTK). Bandung: Alfabeta.

Fraenkel, J.A., and Wallen,N.,E. (1990). How To Design And Evaluate Research In Education (Fifth Edition). Boston: Mc.Graw Hill.

Joyce Bruce, et,al. (2000). Model Of Teaching. London: Allyn Bacon

Moleong, LJ. (2017). Metodologi Penelitian Kualitatif (Edisi Revisi). Bandung: Remaja Rosdakarya.

Mulya,S.(2006). Teori dan Praktik Penelitian Tindakan Kelas Action Research. Bandung: Alfabet.

Kemendikbud. (2013). Pendidkan dan latihan Instruktur PLPG. Bandung: UPI

Permenristekdikti. (2015). Nomor 44 Tahun 2015 Tentang Standar Nasional Pendidikan Tingg. Jakarta: Berita Negara RI Tahun 2015 No. 1952

Sukmadinata, N.,S. (2012). Metode Penelitian Pendidikan. Bandung: PT Remaja Rosda Karya 


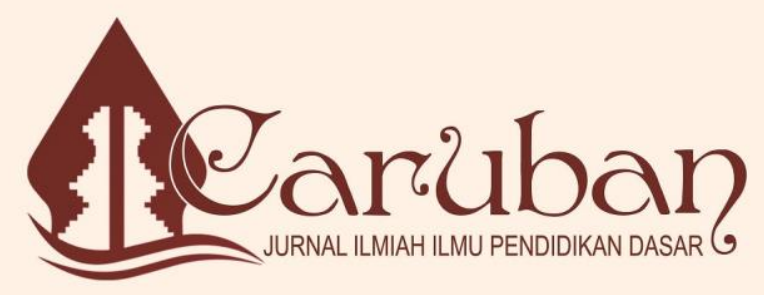

